\title{
EKSTRAKSI DAN KARAKTERISASI SENYAWA METILGALAT DARI BIJI MANGGA INDRAMAYU (Mangifera indica. L).
}

\author{
Zulhipri \\ Jurusan Kimia Fakultas Matematika dan Ilmu Pengetahuan Alam \\ Universitas Negeri Jakarta \\ Email: zulhipri@yahoo.co.id
}

\begin{abstract}
ABSTRAK
Biji mangga Indramayu (Mangifera indica. L) merupakan bagian buah mangga yang terbuang yang belum dimanfaatkan dengan baik. Biji mangga ini diketahui mengandung senyawa bioaktif Metil galat yang memiliki potensi untuk digunakan sebagai bahan obat alami. Tujuan dari penelitian ini dilakukan adalah untuk mendapatkan pelarut ekstraksi yang sesuai dan efektif dalam ekstraksi senyawa Metil galat yang terkandung dalam biji mangga Indramayu. Metoda penelitian yang digunakan adalah ekstraksi perendaman denganp elarut-pelarut polar Metanol, Etanol dan dengan Air panas yang kemudian dilanjutkan dengan pemurnian dan karakterisasi ekstrak dengan Kromatografi Gas Spektrometri Masa (GCMS). Hasil penelitian dari tiga pelarut yang digunakan, menunjukan perolehan ekstraksi senyawa Metilgalat tertinggi pada pelarut Air panas dengan hasil rendemen sebesar 13,58 \%, sedangkan pelarut Metanol dan Etanol menghasilkan Metilgalat dengan rendemen yang lebih rendah yaitu : 5,51\% dan 8,59\%. Dari penelitian ini dapat disimpulkan bahwa pelarut yang paling baik dikembangkan untuk perolehan ekstrak senyawa Metil galat dalam biji mangga Indramayu adalah dengan Air panas.
\end{abstract}

Kata kunci : Bijimangga, Ekstraksi, Metil galat.

\begin{abstract}
Indramayu mango seed (Mangifera indica. L) is part of mango fruit is wasted that have not been put to good use. Mango seed is known to contain bioactive compounds Methyl gallate that has the potential to be used as a natural remedy. The purpose of this research is to obtain an appropriate solvent extraction and effective in extracting Methyl gallate compounds contained in Indramayu mango seed.The research method that is used is soaking with solvent extraction-polar solvents Methanol, Ethanol and with hot water Followed by purification and characterization of the extract by Gas Chromatography Mass Spectrometry (GCMS). The results of the three solvents used, shows the results of extraction of Methyl gallate the highest achievement in the Hot water solvent with the results yield of $13.58 \%$, while the solvent Methanol and Ethanol produces Methyl gallate with a lower yield items are $5.51 \%$ and $8,59 \%$. From this study it can be concluded that the solvent of the most well developed to extract acquisition Methyl gallate compound in Indramayu mango seed is with Hot water.
\end{abstract}

Keywords: Mango seed, Extraction, Methyl gallate. 


\section{PENDAHULUAN}

Mangga (Mangifera indica. L) merupakan salah satu jenis tanaman buah endemik Indonesia. Tanaman ini mulanya berasal dari India, kemudian berkembang ke seluruh dunia termasuk Indonesia. Buah mangga memberikan sumbangan terbesar kedua terhadap produksi buah nasional. Berdasarkan data Badan Pusat Statistik tahun 2012, produksi buah mangga nasional sebesar 2.362.046 ton. Indonesia termasuk 10 negara penghasil mangga terbesar di dunia, terdapat 24 spesies Mangifera tumbuh di Indonesia. Dari spesies Mangifera indica, ada 5 varietas mangga Indonesia yang memiliki nilai ekonomis yang tinggi dan banyak ditanam, yaitu Arumanis, Gedong gincu, Golek, Indramayu dan Manalagi ${ }^{1}$.

Buah mangga mengandung banyak nutrisi yang bermanfaat bagi tubuh, seperti vitamin $\mathrm{A}$, vitamin $\mathrm{B}_{2}$, vitamin $\mathrm{C}$, vitamin $\mathrm{E}$, Karbohidrat, Lemak, Protein, Betakaroten, Tiamin, Riboflavin, Niasin, Asam folat, zat Besi, Posfor, dan Polifenol ${ }^{2}$. Ekstrak buah mangga juga menunjukkan sifat fungsional sebagai, antiinflamasi, antimikrobial, antidiare, dan aktivitas antioksidan, sehingga mangga dikonsumsi sebagai makanan fungsional ${ }^{3}$.

Produksi mangga yang begitu besar sayangnya belum diimbangi dengan pemanfaatannya secara baik oleh masyarakat. Selama ini produk utama dari tanaman mangga adalah daging buah yang dikonsumsi langsung, atau dalam bentuk berbagai produk olahan. Bagian kulit dan bijinya dibuang begitu saja sebagai limbah organik ke lingkungan. Namun demikian, berdasarkan penelitian terhadap tanaman mangga ada bagian lain dari tanaman ini yang bermanfaat sebagai obat alternatif bahan alam. Biji mangga merupakan sumber yang baik dari fitosterol seperti : Kampesterol, $\beta$-sitosterol, Stigmasterol, Tokoferol, Polifenol, dan Tanin ${ }^{4}$.

Biji mangga Arumanis sebelumnya pernah diteliti, dari biji mangga ini telah berhasil diisolasi senyawa golongan fenolik yang teridentifikasi sebagai senyawa Metil galat (Metil-3,4,5-trihidroksi benzoat) $^{5}$. Kemudian dari biji mangga Indramayu juga berhasil diisolasi senyawa Metil galat dengan perolehan hasil isolasi senyawa murni sebanyak 3,56 g, yang memperkuat hasil penelitian sebelumnya tentang kandungan fenolik biji mangga ${ }^{6}$. Senyawa Metil galat, kemudian diketahui merupakan molekul bersifat antioksidan yang potensial dengan $\mathrm{IC}_{50}$ sebesar $2.8 \mathrm{mg} / \mathrm{mL}$, yang menunjukan aktivitas lebih kuat dibanding dengan antioksidan standar senyawa Butilated Hidroksil Anisol (BHA) yang nilai IC 50 nya sebesar $14 \mathrm{mg} / \mathrm{mL}^{7}$. Selain itu senyawa Metil galat juga diteliti bersifat sangat aktif terhadap virus herpes simplek ${ }^{8}$. Kemudian juga dilaporkan bahwa Metil galat dapat meningkatkan efek antitumor atau menghambat pertumbuhan tumor pada tikus ${ }^{9}$.

Penelitian lain tentang Metil galat, yaitu isolasi Metil galat dari beberapa tanaman seperti : Toona sureni, Labisia pumila, dan Alchornia cordifolia ${ }^{7,10,11}$, tapi hasil yang didapat dari tanaman ini relatif sedikit, sedangkan dalam biji mangga telah berhasil diisolasi dengan jumlah yang lebih banyak. Sehingga dengan demikian perlu dilakukan penelitian untuk mendapatkan metoda atau cara memperoleh senyawa Metil galat dalam biji mangga, agar nanti dapat dimanfaatkan, baik sebagai makan fungsional yang menyehatkan, maupun sebagai sumber bahan obat yang potensial. Biji mangga yang digunakan dalam penelitian ini adalah dari jenis Indramayu, karena biji mangga Indramayu ini telah terbukti mengandung senyawa fenolik yang tinggi.

\section{METODE PENELITIAN}

\section{Bahan}

Bahan yang digunakan adalah : Metanol, Etanol, Etil asetat, Aseton, Kloroform, nHeksana, Akuades, $\mathrm{FeCl}_{3}$, Kertas saring dan alat gelas pendukung lainnya. 


\section{Peralatan}

Peralatan yang digunakan dalam penelitian ini adalah : Alat ekstraksi (Maserasi), Kromatografi Lapis Tipis (plat KLT dan Camber). Timbangan analitik. Kromatografi Gas Spektrometer Massa (GCMS).

\section{Prosedur}

\section{Persiapan Sampel}

Biji mangga Indramayu dikupas dibuang kulit bijinya, diambil kernelnya kemudian diiris, dikering anginkan, selanjutnya digiling sampai diperoleh serbuk kering.

\section{Ekstraksi}

Serbuk kering biji mangga diektraksi (maserasi) dengan berbagai pelarut. Ekstraksi pertama dilakukan dengan pelarut non polar n-Heksana untuk menghilangkan lemak. Kemudian dilanjutkan ekstrak dengan pelarut pelarut polar : Etanol, Metanol dan Air panas. Ekstraksi dilakukan berulang-ulang sampai tes fenolik negatif. Ekstrak dikumpulkan kemudian diuapkan pelarutnya dengan rotavapor.

\section{Pemurnian}

Pemurnian dilakukan dengan teknik kristalisasi dengan sistem dua pelarut yang sesuai dan berbeda kepolaran.

\section{Karakterisasi}

Karakterisasi dilakukan dengan Kromatografi Lapis Tipis (KLT) dan Kromatografi Gas Spektrometri Massa (GCMS).

Senyawa Metil galat hasil ekstraksi ditentukan rendemennya terhadap berat kering sampel biji mangga.

\section{HASIL DAN PEMBAHASAN}

\section{Ekstraksi.}

Ekstraksi adalah proses penarikan komponen senyawa dari campurannya. Pada penelitian ini ekstraksi dilakukan dengan tiga jenis pelarut polar yaitu : Metanol, Etanol dan Air panas. Tujuan menggunakan tiga pelarut ini untuk mendapatkan pelarut yang cocok dan paling baik untuk ekstraksi senyawa Metil galat dalam biji mangga Indramayu. Ekstraksi serbuk kering biji mangga Indramayu masing-masing sebanyak 50 gram menghasilkan ekstrak kental berwarna coklat tua sebagai berikut :

Tabel 1. Berat ekstrak dan rendemen biji mangga Indramayu

\begin{tabular}{|c|l|c|c|c|}
\hline No & Pelarut & $\begin{array}{c}\text { Berat Biji } \\
\text { Mangga kering } \\
\text { (gram) }\end{array}$ & $\begin{array}{c}\text { Berat Ekstrak } \\
\text { (gram) }\end{array}$ & $\begin{array}{c}\text { Rendemen } \\
(\%)\end{array}$ \\
\hline 1 & Metanol & 50 & 13,28 & 26,56 \\
\hline 2 & Etanol & 50 & 14,62 & 29,24 \\
\hline 3 & Air panas & 50 & 15,74 & 31,48 \\
\hline
\end{tabular}


Dari ketiga pelarut yang digunakan, diperoleh berat ekstrak yang berbeda dengan hasil terbanyak pada pelarut Air panas dengan rendemen 31,48\%. Hal ini menunjukan bahwa ekstraksi senyawa yang terkandung dalam biji mangga dapat dilakukan dengan menggunakan pelarut selain pelarut organik seperti Metanol dan Etanol.

\section{Uji Fitokimia.}

Metil galat adalah senyawa golongan fenolik yang sebelumnya telah diisolasi dari biji mangga jenis Arumanis dan Indramayu. Uji fitokimia dilakukan dengan menggunakan reagen $\mathrm{FeCl}_{3}$, untuk mengetahui kandungan senyawa fenolik dalam ekstrak. Hasil uji fitokimia terhadap ketiga ekstrak menunjukkan kandungan senyawa fenolik tinggi yang ditandai dengan terbentuknya endapan pekat berwarna ungu tua, sehingga dengan demikian dapat diduga ekstrak yang diperoleh mengandung senyawa Metil galat.

\section{Analisis Kromatografi Lapis Tipis (KLT).}

Analisis KLT bertujuan untuk memisahkan dan memantau hasil ekstraksi yang diperoleh. KLT dilakukan dengan menggunakan eluen pada penelitian sebelumnya, yakni campuran pelarut Klorofrm : Etil asetat $(4: 6) .{ }^{6}$ Hasil KLT untuk ketiga kondisi ekstraksi adalah sebagai berikut :

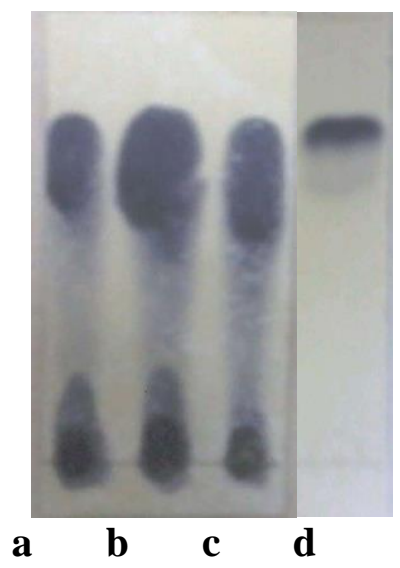

Gambar 1. Kromatogram KLT Ekstrak dan Metil galat dengan eluen Kloroform : Etil asetat (3:7). $\mathrm{a}=$ Metanol, $\mathrm{b}=$ Etanol, $\mathrm{c}=$ Akuades panas, $\mathrm{d}=$ Metil galat

Pada kromatogram KLT yang dihasilkan terlihat hasil pemisahan yang baik untuk ketiga ekstrak, yaitu terdapat noda dominan dengan $\mathrm{Rf}=0,68$. Warna ungu yang muncul pada noda ketika diberi pereaksi $\mathrm{FeCl}_{3}$, dan harga $\mathrm{Rf}$ yang sama dengan Metil galat, menunjukkan bahwa noda tersebut merupakan senyawa fenolik Metil galat.

\section{Pemurnian dengan Kristalisasi.}

Untuk mendapatkan ekstrak yang lebih murni, selanjutnya dilakukan kristalisasi dengan menggunakan dua pelarut dengan kepolaran berbeda. Setelah dilakukan berbagai pelarut, ditemukan pelarut yang cocok yaitu Etil asetat dan n-Heksana. Kristalisasi dilakukan berulang kali sampai terbentuk endapan yang bersih, dan larutannya menjadi jernih. Hasil kristalisasi terhadap semua ekstrak diperoleh padatan dengan warna kecoklatan dengan berat ekstrak berturut turut untuk ekstrak Metanol, Etanol, dan Air panas sebanyak 4,70 gr ; 6,23 gr ; 7,35 gr. Hasil ini diperhitungkan sebagai rendemen seperti pada Tabel 2 . 
Tabel 2. Hasil rendemen ekstrak biji mangga hasil kristalisasi

\begin{tabular}{|c|l|c|c|c|}
\hline No & Pelarut & $\begin{array}{c}\text { Berat Sampel } \\
\text { (gram) }\end{array}$ & $\begin{array}{c}\text { Berat Ekstrak } \\
\text { (gram) }\end{array}$ & $\begin{array}{c}\text { Rendemen } \\
(\%)\end{array}$ \\
\hline 1 & Metanol & 50 & 4,70 & 9,40 \\
\hline 2 & Etanol & 50 & 6,23 & 12,46 \\
\hline 3 & Air panas & 50 & 7,35 & 14,70 \\
\hline
\end{tabular}

\section{Karakterisasi dengan GCMS.}

Analisis dengan Kromatografi Gas Spektrometer Masa (GCMS) bertujuan untuk mengkarakterisasi jenis senyawa hasil ekstraksi. Pada Kromatografi Gas, zat-zat dapat dipisahkan satu sama lain berdasarkan sifat kepolaran zat. Puncak-puncak yang mucul merupakan representasi dari molekul yang terpisah sesuai dengan waktu retensi setiap zat yang dianalisis. Luas area puncak yang dihasilkan merupakan perbandingan relatif kandungan zat dalam sampel yang dianalisis. Selanjutnya hasil pemisahan Kromatografi Gas ini kemudian dianalisis dengan Spektrometer Masa yang menghasilkan spektrum berupa puncak-puncak fragmen molekul yang diinterpretasikan menjadi struktur molekul dan masa molekul. berikut.

Hasil Analisis GCMS untuk ketiga jenis ekstrak diperoleh kromatogram GC sebagai

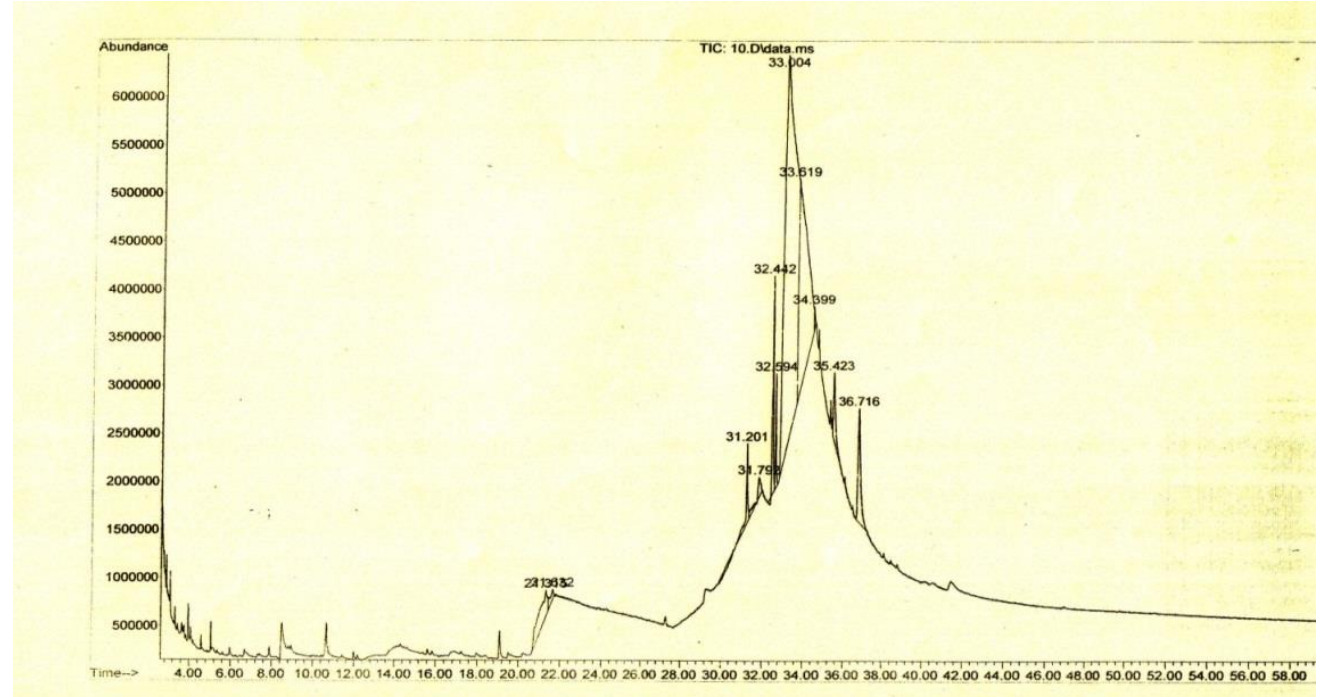

Gambar 2. Kromatogram GC Ekstrak Metanol

Hasil analisis GC untuk ekstrak Metanol, terdapat puncak dominan dengan intenitas paling tinggi, yaitu dengan waktu retensi 33,04. Terhadap puncak ini kemudian dilakukan analisis spekroskopi masa, dengan hasil spektrum masa sebagai berikut : 


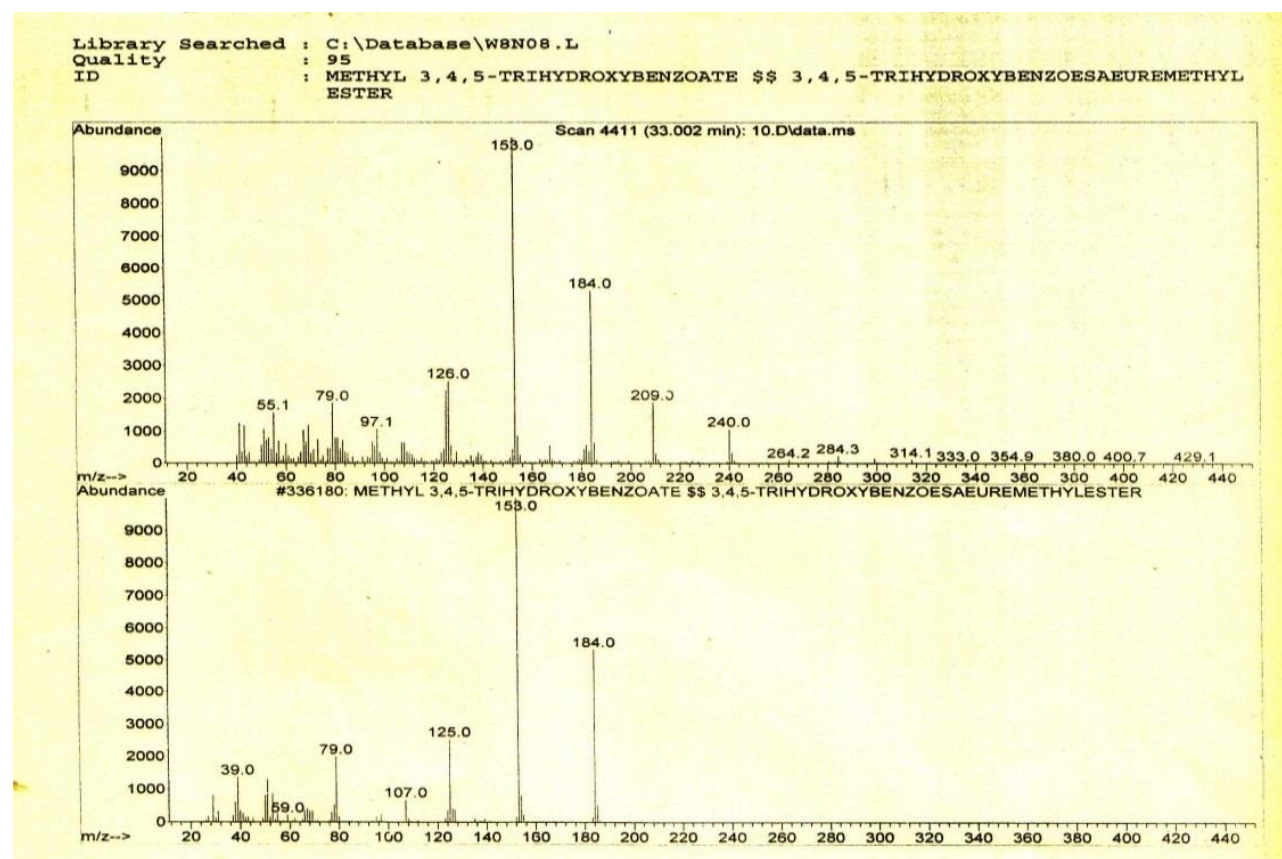

Gambar 3 . Kromatogram masa senyawa dengan waktu retensi 33,002 dalam ekstrak Metanol

Pada spektrum masa di atas terlihat bahwa senyawa yang dianalisis memiliki kesamaan dengan data pembanding yang merupakan senyawa dengan masa ion molekul $(\mathrm{m} / \mathrm{z})=184$ dan mempunyai puncak dasar dengan $(\mathrm{m} / \mathrm{z})=153$, yang merupakan senyawa Metil 3,4,5-trihidroksi benzoat atau Metil galat. Analisis persen kemiripan (data pada Lampiran 1) untuk senyawa ekstrak metanol ini sebesar 95\%, dengan persen luas area sebesar 58,62\%. Dengan kualitas kemiripan melebihi 90\%, dapat dinyatakan bahwa senyawa yang dianalisis merupakan senyawa yang sama dengan senyawa referensi pembanding. Kemudian dari persen perbandingan luas area yang hanya sebesar 58,62\%, menunjukkan bahwa kandungan ekstrak metanol ini masih banyak mengandung campuran zat lain yang bukan Metil galat.

Demikian juga untuk ekstrak Etanol didapat hasil spektrum GC sebagai berikut : 


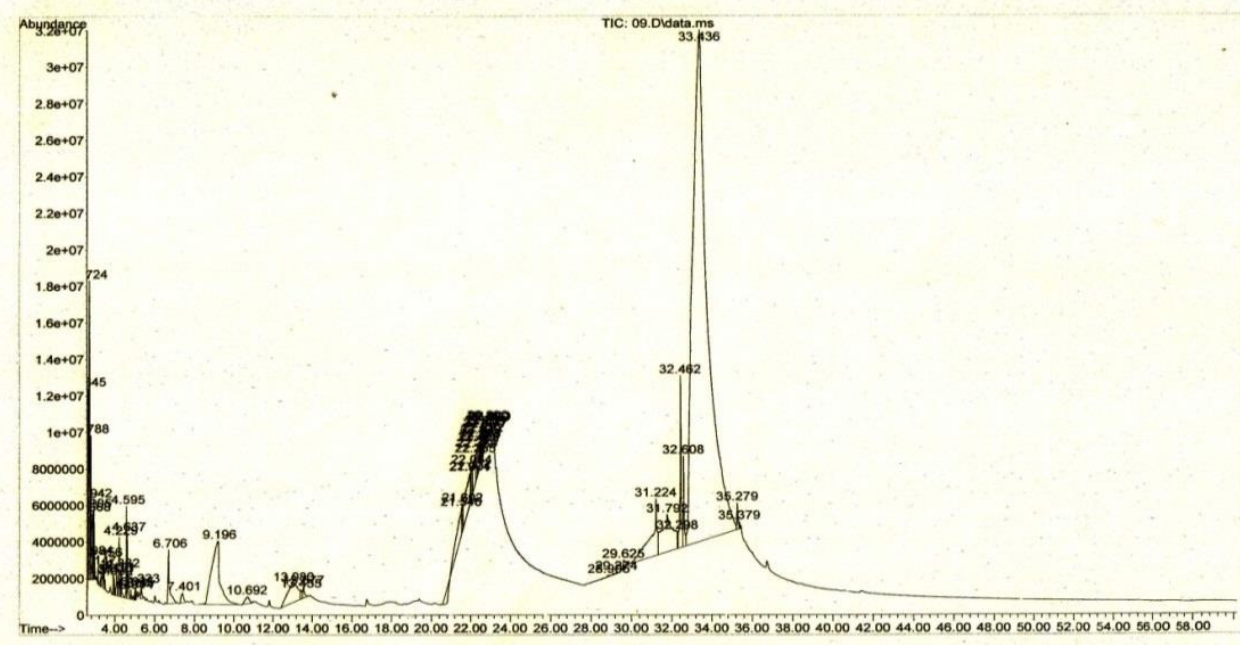

Gambar 4. Kromatogram GC ekstrak Etanol

Puncak dominan yang dihasilkan pada kromatogram GC adalah puncak dengan waktu retensi 33, 436, yang selanjutnya dianalisis dengan spektroskopi masa sehingga dihasil spektrum berikut :

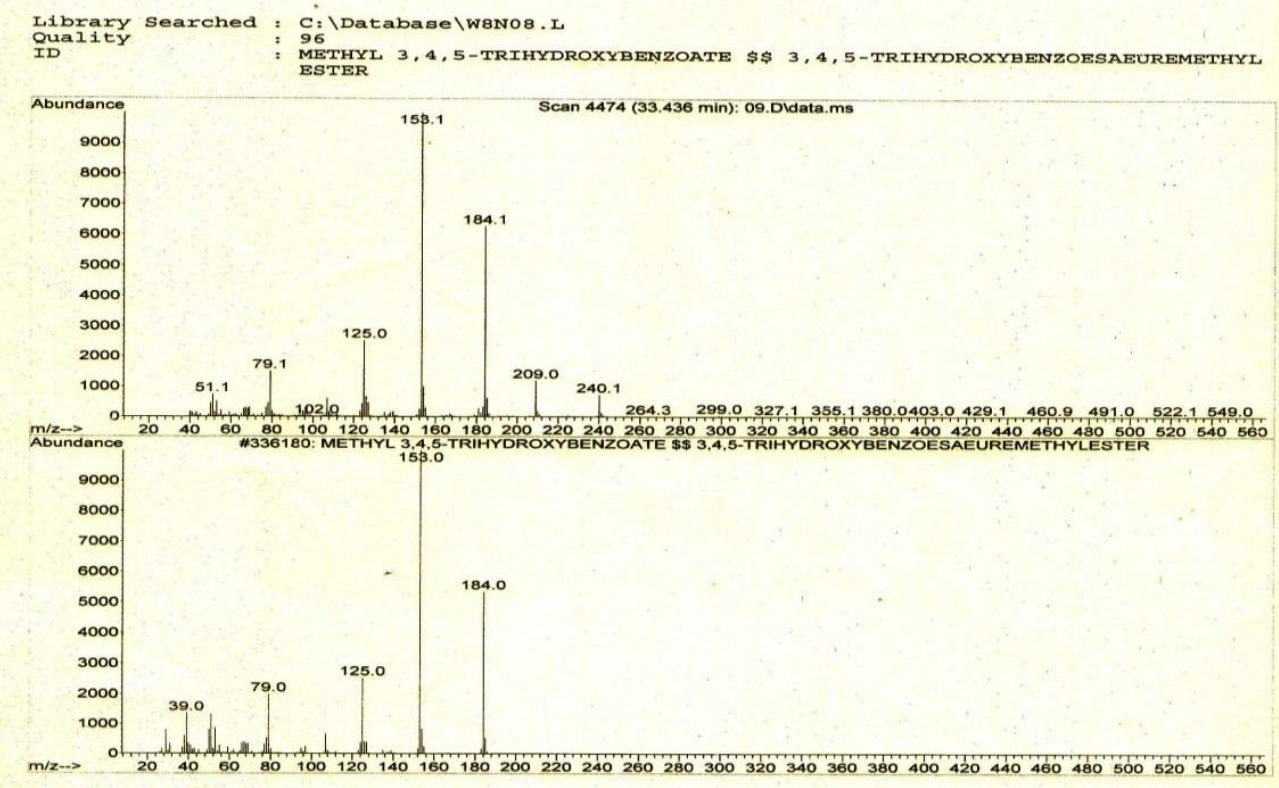

Gambar 5. Kromatogram masa senyawa waktu retensi 33,436 ekstrak Etanol

Analisis Spektrum MS, menunjukan senyawa dengan waktu retensi 33,436 juga merupakan senyawa Metil 3,4,5-trihidroksi Benzoat (Metil galat). Persen kemiripan dan perbandingan luas area (Lampiran 2), menunjukan data untuk senyawa dengan waktu retensi 33,346 mempunyai kualitas kemiripan sebesar $96 \%$. Sedangkan perbandingan luas areanya sebesar 68,91 \% . Hasil ini menunjukan bahwa ekstrak etanol juga masih banyak mengandung senyawa lain selain Metil galat.

Analisis terhadap ekstrak Air panas, diperoleh spektrum GC sebagai berikut : 


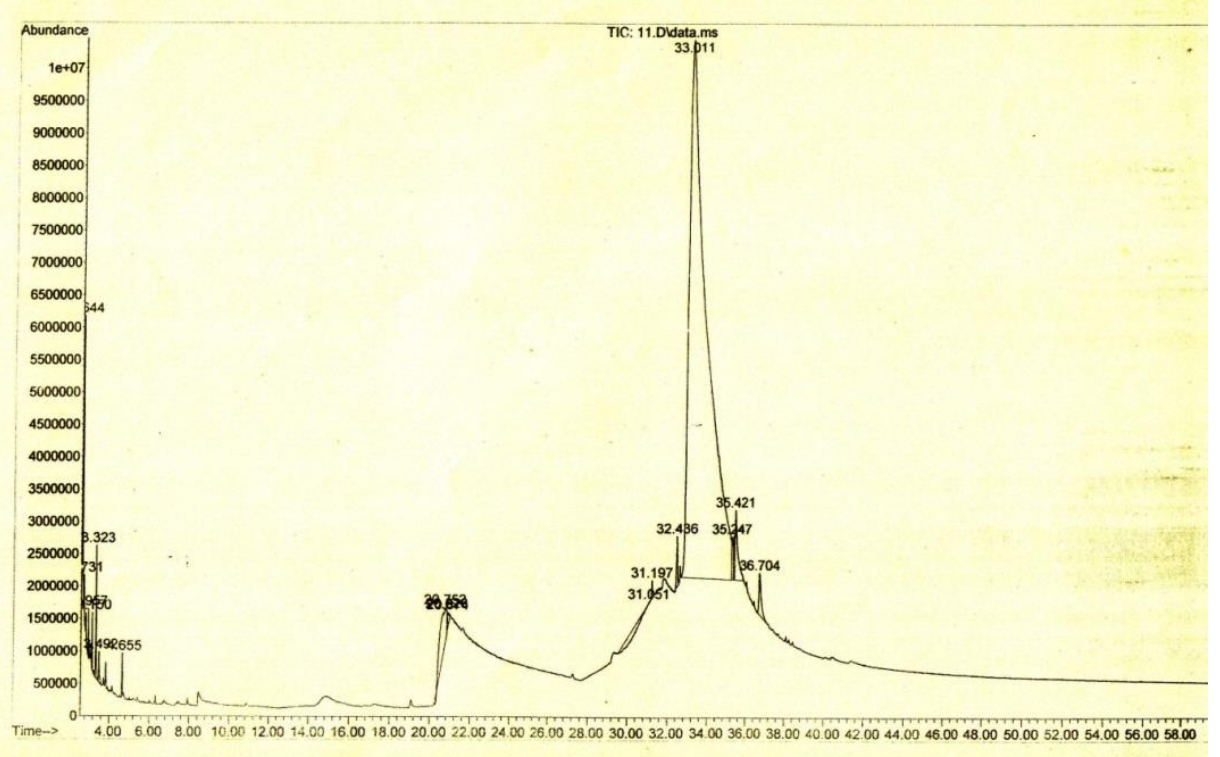

Gambar 6. Kromatogram GC ekstrak Air panas

Hasil analisis ekstrak Air panas di peroleh puncak dominan pada waktu retensi sebesar 33,011. Puncak dominan ini selanjutnya juga dianalisis spektroskopi masanya dengan hasil spektrum sebagai berikut :

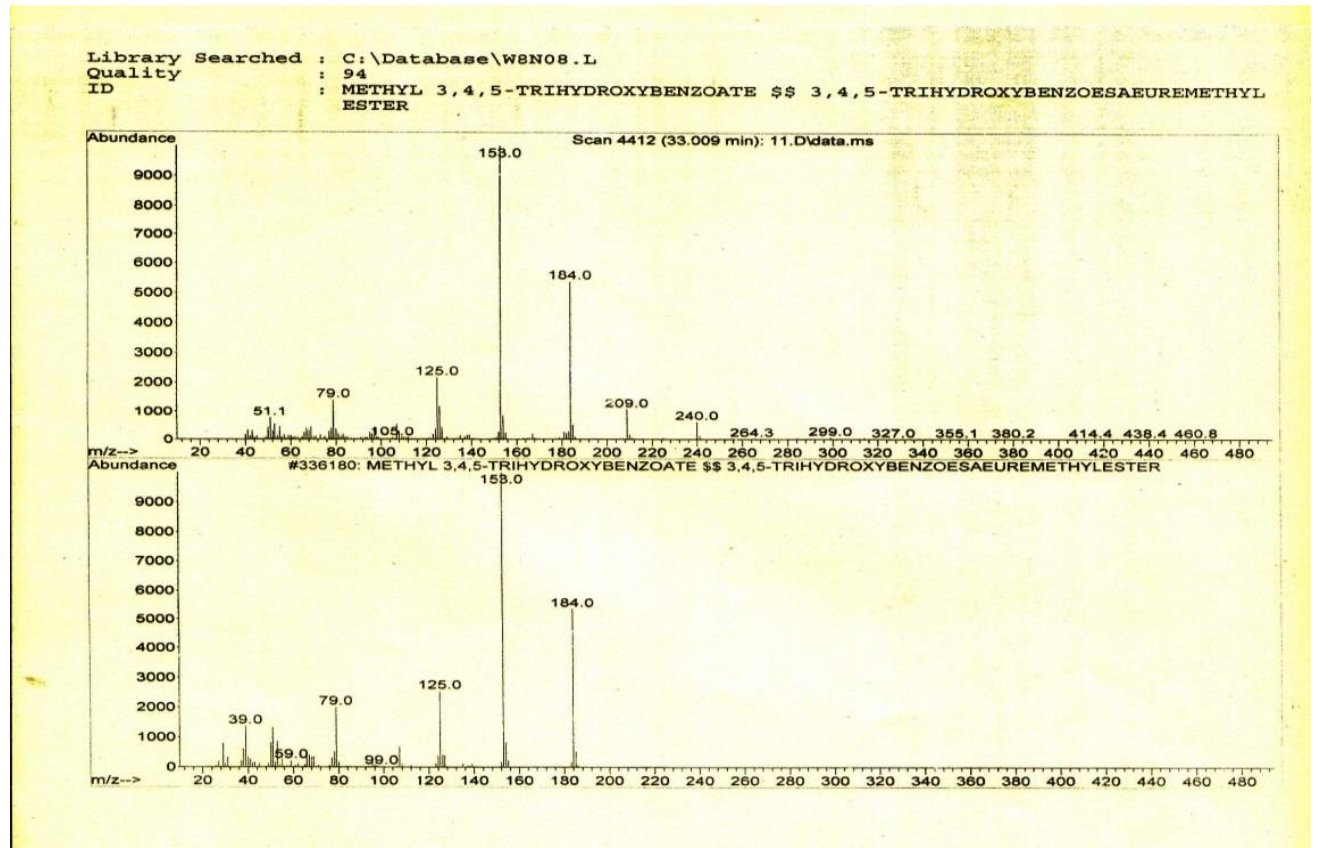

Gambar 7. Kromatogram masa senyawa waktu retensi 33,011 ekstrak Air panas

Dari spektrum ini juga menunjukan bahwa senyawa dengan waktu retensi 33,011 merupakan senyawa Metil galat. Kualitas persen kemiripan untuk senyawa ini adalah sebesar 94\%. Dengan demikian dapat dipastikan bahwa senyawa ini juga merupakan senyawa Metil galat. 
Kemudian dari data perbandingan luas area untuk senyawa waktu retensi 33,011 (Lampiran 3) menunjukan nilai yang tinggi yaitu sebesar 92,38 \%. Dari perbandingan nilai luas area yang tinggi ini dapat disimpulkan bahwa, ekstraksi dengan menggunakan ai Air panas dapat menarik senyawa Metil galat dalam biji mangga Indramayu dengan hasil lebih banyak dibandingkan pelarut polar lain Metanol dan Etanol yang hanya dengan perbadingan luas area pada GC sebesar 58,62 \% dan 68,91\%.

Untuk keseluruhan rendemen senyawa Metil galat hasil karakterisasi berdasarkan perbandingan luas area yang dihasilkan, dapat dihitung rendemen senyawa Metil galat sebagai perkalian persen luas area dengan persen rendemen ekstrak hasil pemurnian, sehingga nilai rendemen senyawa Metil galat hasil ekstraksi pelarut adalah sebagai berikut:

Tabel 3. Rendemen Metil galat hasil karakterisasi GCMS

\begin{tabular}{|c|l|c|c|c|}
\hline No & Pelarut & $\begin{array}{c}\text { Rendemen Ekstrak } \\
(\%)\end{array}$ & $\begin{array}{c}\text { Persen Area } \\
(\%)\end{array}$ & $\begin{array}{c}\text { Rendemen Metil galat } \\
(\%)\end{array}$ \\
\hline 1 & Metanol & 9,40 & 58,62 & 5,51 \\
\hline 2 & Etanol & 12,46 & 68,91 & 8,59 \\
\hline 3 & Air panas & 14,70 & 92,38 & 13,58 \\
\hline
\end{tabular}

Dari karakterisasi persen area yang dihasilkan ini dapat disimpulkan bahwa pelarut yang menghasilkan rendemen senyawa Metil galat tertinggi adalah pelarut Air panas dengan nilai sebesar $13,58 \%$.

\section{KESIMPULAN}

1. Ekstraksi biji mangga Indramayu dengan pelarut polar Metanol, Etanol dan Air panas menghasilkan ekstrak kental berwarna coklat tua dengan komponen utama senyawa golongan Fenolik dengan rendemen berturut sebesar 25,56\% ; 29,24\% dan 31,48\%.

2. Hasil karakterisasi ekstrak dengan Kromatografi Gas Spektrometri Masa memastikan bahwa senyawa Metil galat telah berhasil diekstraksi dengan rendemen tertinggi pada pelaut Air panas. Nilai rendemen senyawa Metil galat masing-masing pelarut Metanol, Etanol, dan Air panas berturut adalah : 5,51\% ; 8,59\% dan 13,58\%.

\section{DAFTAR PUSTAKA}

1. Rebin. Karsinah. Soemargono, A. 2013. Peningkatan Produktivitas dan Kualitas Mangga Komersial Indonesia Melalui Pemuliaan dan Pengelolaan Tanaman. http://www.mada.gov.my/documents/10124/b71dcdba-2310-497d-a7a3ddd65049b757.

2. Pino J A, Mesa J, Munoz Y, Marti MP and Marbot R. 2005. Volatile Components from Mango (Mangifera indica L.) Cultivars. J. Agr. Food chem. 53. 2213- 2223.

3. Pracaya, 1989. Bertanam Mangga. Jakarta: Penebar Swadaya.

4. Puravankara D, Boghra V, Sharma R. S. 2000. Effect of antioxidant Principles isolated from mango (Mangifera indica L.) seed kernels on oxidative stability of buffalo ghee (butter-fat). Jour. Sci Food. Agr 80 (4) . 522-526.

5. Zulhipri., Yusnetty Boer, Resa Rahmawatie, Siti Julekha. 2011. Profil Fitokimia dan Uji Antibakteri Biji Mangga Arumanis. Mesomeri (1), 9-13.

6. Zulhipri, Yusnetty Boer, Saidah. 2013. Isolasi Senyawa Fenolik dari Biji Mangga Indramayu (Mangifera indica. L) Proseding Seminar Nasional Tumbuhan Obat ke 44. Palembang. 
7. M.Taufik Ekaprasada, Hazli Nurdin, Sanusi Ibrahim, and Dachriyanus. 2009. Antioxidant Activity of Methyl Gallate Isolated from The Leaves of Toona sureni. Indo. J. Chem., 9 (3), 457 - 460

8. Cynthia J. M. Kane, Jay H. Menna, Ching-Ching Sung and Yun-Chi Yeh.1988. Methyl Gallate, Methyl-3,4,5-trihydoxybenzoate, is a Potent and Highly specific Inhibitor of Herpes Simplex Virus in vitro. Bioscience Reports, 8(1).

9. Heekyung Lee, Hyojung Lee, Youngjoo Kwon, Jun-Ho Lee, Jinju Kim, Min-Kyu Shin, Sung-Hoon Kim and Hyunsu Bae. 2010. Methyl Gallate Exhibits Potent Antitumor Activities by Inhibiting Tumor Infiltration of CD4+CD25+ Regulatory $T$ Cells. J Immunol. 185:6698-6705.

10. D. Mohd Nazrul Hisham, J. Mohd Lip, J. Mohd Noh, A. Normah dan M.F. Nurul Nabilah(2011). Identification and isolation of methyl gallate as a polar chemical marker for Labisia pumila Benth. J. Trop. Agric. and Fd.D S.c. 39(2) : 279-284

11. Talba, A. M., Suleiman, M. M., Raji, M. A., Oniye, S. J. 2014. Phytochemical Screening and In-vitro Antibacterial Activity of Mangifera indica (Mango) Kernel on Aeromonas caviae. Journal Of Pharmacy(4). 45-50. 